\title{
Preventive blood evaluation in obese dogs (Canis lupus familiares)
}

\section{Análise sanguínea preventiva em cães obesos (Canis lupus familiares)}

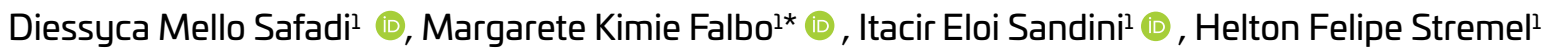

\begin{abstract}
The objective of this study was to evaluate serum hematological and biochemical changes in obese young dogs clinically healthy. Twenty-six animals were selected, which were separated into two groups: thirteen with normal weight and thirteen with obesity. Exclusion criteria were used for the selection of groups, age between one and eight years, physical evaluation, blood count, and a questionnaire to investigate pre-existing pathologies (diabetes mellitus, hypothyroidism, hyperadrenocorticism, hepatic and/or renal insufficiency, congenital or acquired heart disease, locomotor problems, inflammatory and/or infectious diseases or physiological conditions such as pregnancy or lactation). 5-mL blood samples were collected from each patient by puncture of the cephalic vein in the morning after a feeding restriction of 10 hours. Hematocrit, total erythrocyte count, hemoglobin concentration, total leukocyte count, leukocyte differential count and serum albumin, total protein, globulins, ALT, ALP, HDL cholesterol, total cholesterol, triglycerides, creatinine, urea, glucose, and insulin were assessed. No statistically significant differences were found between the groups in the hematological assessments. Among the biochemical tests, there were significant differences in total cholesterol, HDL cholesterol, and glucose ( $\mathrm{p} \leq 0.05)$.
\end{abstract}

KEYWORDS: Dyslipidemia, hypercholesterolemia, obesity, preinflammatory condition.

RESUMO: O objetivo deste estudo foi avaliar as alteraçóes hematológicas e bioquímicas séricas em cães jovens, obesos, e clinicamente saudáveis. Foram selecionados 26 animais e separados em dois grupos: 13 com peso normal e 13 com obesidade. Foram utilizados critérios de exclusão para seleção de grupos como: idade entre um e oito anos, avaliação física, hemograma completo e um questionário com o objetivo de investigar patologias pré-existentes (diabetes mellitus, hipotireoidismo, hiperadrenocorticismo, insuficiência hepática e, ou renal, doença cardíaca congênita ou adquirida, problemas locomotores, doenças inflamatórias e, ou infecciosas ou condições fisiológicas como gravidez ou lactação). Amostras de $5 \mathrm{~mL}$ de sangue foram coletadas de cada paciente por punção da veia cefálica na manhã seguinte a uma restrição alimentar de 10 horas. Foram avaliados: hematócrito, contagem total de eritrócitos, concentração de hemoglobina, contagem total de leucócitos e albumina sérica, ALT, colesterol HDL, colesterol total, creatinina, ALP, frutosamina, globulinas, glicose, insulina, proteína total, sódio, triglicerídeos e uréia. Não foram encontradas diferenças estatisticas significantes entre os grupos nas avaliações hematológicas. Entre os testes bioquímicos, houve diferenças significativas no colesterol total, HDL-colesterol e glicose $(\mathrm{p} \leq 0,05)$.

PALAVRAS-CHAVE: Dislipidemia, hipercolesterolemia, obesidade, condição pré-inflamatória

\section{INTRODUCTION}

Obesity is considered a very common nutritional disorder in dogs and is a major risk factor for several diseases (GERMAN, 2010), which can lead to comorbidities such as locomotor system disorders, impairment of the immune response, cardiorespiratory, endocrine (LAFLAMME, 2006), dermatological, reproductive and dyslipidemic diseases; and longevity interference (KEALY et al., 2002). Obesity is becoming a medical concern as the prevalence is increasing not only in dogs but also in their owners (GERMAN, 2010).

In dogs and cats, obesity can trigger several metabolic disorders because adipose tissue is an endocrine organ that participates in the metabolism of lipids, carbohydrates, and energy regulation. However, the association between obesity and metabolic syndrome (MS) in veterinary medicine is still widely discussed and controversial (CLARK; HOENIG, 2016).

The objective of this study was to determine differences in hematological and serum biochemical indices in normalweight and obese dogs.

\section{MATERIALS AND METHODS}

Animals. This study was approved by the Committee on Ethics and Animal Experimentation, under the approval of $\mathrm{N}^{\circ} 027 / 2016$. A total of 50 animals were evaluated and, after applying the exclusion criteria, 26 adult dogs were selected and separated into two groups: 13 with normal weight (NW) 
and 13 with obesity $(\mathrm{OB})$ as suggest by Tvarijonaviciute et al. (2012).

The exclusion criteria utilized for the selection of these patients were age, between one and eight years (to minimize variations in body composition due to the process of growth or aging), and healthy (anamnesis, physical evaluation, hemogram). Patients with endocrine disorders such as diabetes mellitus, hypothyroidism, and hyperadrenocorticism were excluded from this study, as well as those with hepatic and/ or renal insufficiency, congenital or acquired heart disease, inflammatory disorders and/or infections; additionally, patients with physiological conditions such as pregnancy or lactation were excluded. Variations in factors such as sex, castration, race, or diet were not considered in the selection of patients.

All animals were submitted to clinical examination and assessment of body condition. The body condition score (BCS) of each patient was determined, and dogs with a score of $\geq 7 / 9$ were considered obese, while those with a score of $5 / 6$ were classified as normal weight (TVARIJONAVICIUTE et al., 2012). Body mass index (BMI) was calculated according to the formula: weight $(\mathrm{kg}) /$ height $(\mathrm{m})^{2}$; those with a BMI between 11.8 and 15 were considered normal weight, and those with values above 18.7 were considered obese. For large dogs with more than $25 \mathrm{~kg}$ of body weight, the value obtained by the formula was reduced by $20 \%$. For small dogs weighing less than $10 \mathrm{~kg}$, the value obtained was increased by $10 \%$. The weight in kilograms was obtained with the use of a digital scale, and to determine the height of the animal, the length of the spine was measured, considering the extension of the atlanto-occipital joint as a reference point; the flexible measuring tape was passed over the last sacral vertebra up to the ground immediately behind the pelvic limbs (MULLER et al., 2008).

The waist circumference (WC) was measured without excessive pressure or slack on the measuring tape. For body fat (BF) values, the normal range was considered to be between $15 \%$ and $25 \%$, while values above $30 \%$ indicated obesity (CLARK; HOENIG, 2016).

For the determination of BF, the following calculation was performed (BURKHOLDER; TOLL, 2010):

BF females $(\%)=-1.7(\mathrm{LRH} \mathrm{cm})+0.93(\mathrm{WC} \mathrm{cm})+5$ and $\mathrm{BF}$ males $(\%)=-1.4(\mathrm{LRH} \mathrm{cm})+0.77(\mathrm{WC} \mathrm{cm})+4$. Where the LRH (length of the right posterior limb from the shell of the calcaneus to the medium patellar ligament) corresponds to the distance between the calcaneal shell and the middle patellar ligament of the right pelvic limb.

Blood tests. Samples of $5 \mathrm{~mL}$ of blood were collected in the morning by puncture of the cephalic vein after food fasting of 10 hours. The samples with EDTA-K3 anticoagulant (ethylene diamine potassium tetraacetate), $6 \mathrm{~g} / \mathrm{dL}$ associated with fluoride a $12 \mathrm{~g} / \mathrm{dL}$ (Glistab) to perform the blood count (SDH-3 VET"), for determining the hematocrit, total erythrocyte count, hemoglobin concentration, total leukocyte count, leukocyte differential count.
The tubes without anticoagulant and with fluoride were centrifuged at $1500 \times \mathrm{g}$ for 15 minutes to obtain serum and plasma. The parameters were analyzed with Labtest kits, determined by colorimetry in a semiautomatic biochemical analyzer (BIO PLUS 200): total protein, albumin, globulin were calculated by subtraction of total proteins and albumin, alanine aminotransferase (ALT), alkaline phosphatase (ALP), total cholesterol, HDL cholesterol, triglycerides, creatinine, urea, glucose, and insulin.

Statistical Analysis. The data obtained were tabulated and analyzed by Tukey's test with a 5\% probability level, with the SISVAR statistical analysis program comparing the data obtained between the groups ( $\mathrm{p} \leq 0.05)$.

\section{RESULTS}

Baseline characteristics of canine participants. Of the 13 obese dogs selected, 9 were female ( 7 sterilized and 2 not sterilized) and 4 were males ( 3 sterilized and 1 not sterilized). In the group of dogs with normal weight, 8 were males ( 6 unsterilized and 2 sterilized) and 5 were females ( 4 unsterilized and 1 sterilized). The mean age of the obese group was 4.46 years, and of the group with normal weight, the mean age was 3.08 years, reflecting the prevalence of young animals.

Regarding the CSE, the mean of the obese group was 8.15, while for the control group, it was $4.77(\mathrm{p}<0.01)$. The mean BMI of the obese group was 19.75 , while that of the group with normal weight was $14.12(\mathrm{p}<0.01)$. The average percentage of BF among the obese dogs was $33.28 \%$, while for the dogs with normal weight, it was $21.13 \%(\mathrm{p}<0.01)$.

Serum Biochemistry and Hemograms. There were no statistically significant differences between the groups in the values of the blood count and total leukocyte count (Table 1).

The results of the biochemical analyses are presented in Table 2. It was observed that the obese group presented higher serum values of total cholesterol, HDL cholesterol, and glucose, with a statistically significant difference. For triglycerides, globulins, and total protein, there was a tendency toward higher values in the obese group $(\mathrm{p} \leq 0.1)$.

Hypercholesterolemia was found in $15.38 \%$ of obese patients, HDL cholesterol was higher in $46.15 \%$ of obese patients, and hypertriglyceridemia was found in $23.08 \%$ of obese patients.

\section{DISCUSSION}

In this work, it was observed that the animals in the obese group were young adults, which is worrying because there is a tendency for weight gain to increase with age (DIEZ, 2006). Unfortunately, in Brazil, there are no data on obesity in dogs.

The result was similar to that observed in humans so studies conducted in the USA reported that $17 \%$ of American children and adolescents aged 2 to 19 years old were obese. This fact has raised many discussions about how the lifestyle of the owners (diet and physical activity) and the environment in 
which they live influence animals and whether obesity should be considered unhealthy because some disorders resulting from obesity are common among species; the understanding of correlated pathologies could open opportunities that lead to the prevention of obesity in both animals and humans (CHANDLER et al., 2017).

In humans, obesity is related to inflammatory diseases with the production of pro-inflammatory cytokines, such as interleukin-6 and alpha tumor necrosis factor, which cause persistent, low-grade inflammation; therefore, there is usually no evident change in the leucogram, but there is a greater production of globulins (ECKERSALL, 2008).

In this study, we did not observe any change in the leucogram (Table 1), which suggests that there was no evident inflammatory response at the time of evaluation and that the leukocyte patterns do not change in obese patients. However, when analyzing the serum globulin concentration, we verified that the obese group tended to have higher values, which could indicate a preinflammatory condition with increased specific acute phase proteins and thus increased serum globulin

Table 1. Reference values, confidence intervals, and P-values of the hemograms of dogs with normal weight and obesity.

\begin{tabular}{|c|c|c|c|c|c|}
\hline \multirow[b]{2}{*}{ Parameters } & \multirow[b]{2}{*}{ Unit } & \multirow{2}{*}{$\begin{array}{c}\text { Reference } \\
\text { values }\end{array}$} & \multicolumn{2}{|c|}{ Confidence interval (95\%) } & \multirow[b]{2}{*}{ P-value } \\
\hline & & & $\begin{array}{l}\text { Normal weight } \\
\qquad(n=13)\end{array}$ & $\begin{array}{l}\text { Obese } \\
(n=13)\end{array}$ & \\
\hline Erythrocyte & $\times 10^{6} / \mu \mathrm{L}$ & $5.5-8.5$ & $6.4-7.4$ & $6.7-7.6$ & 0.419 \\
\hline Hemoglobin & $\mathrm{g} / \mathrm{dL}$ & $12-18$ & $13.2-15.4$ & $14.3-16.8$ & 0.175 \\
\hline Hematocrit & $\%$ & $37-55$ & $40-46,8$ & $41.9-47.6$ & 0.585 \\
\hline Leukocytes & $/ \mu \mathrm{L}$ & $6000-17000$ & $9843.4-12825.1$ & $10627.2-13129.1$ & 0.537 \\
\hline Band neutrophils & $/ \mu \mathrm{L}$ & $0-300$ & $34.5-434.6$ & $34.9-201.8$ & 0.374 \\
\hline Neutrophils & $/ \mu \mathrm{L}$ & $3000-11500$ & $6078-8533.8$ & $6541.7-8636.3$ & 0.726 \\
\hline Lymphocytes & $/ \mu \mathrm{L}$ & $1000-4800$ & $1940.5-3223.4$ & $2518.3-4236.1$ & 0.175 \\
\hline Eosinophils & $/ \mu \mathrm{L}$ & $150-1250$ & $684.1-1689.9$ & $338.8-1058.5$ & 0.223 \\
\hline Monocytes & $/ \mu \mathrm{L}$ & $150-1350$ & $8.9-58.5$ & $28.6-180.3$ & 0.402 \\
\hline Platelets & $\times 103 / / \mu \mathrm{L}$ & $200-500$ & $189.33-289.39$ & $182.62-291.0$ & 0.949 \\
\hline
\end{tabular}

tReference values according to Schalms's (2010)

Table 2. Reference values, confidence intervals, and $\mathrm{P}$ values of the serum biochemical tests of dogs with normal weight and obesity.

\begin{tabular}{|c|c|c|c|c|c|}
\hline \multirow[b]{2}{*}{ Parameters } & \multirow[b]{2}{*}{ Unit } & \multirow[b]{2}{*}{$\begin{array}{c}\text { Reference } \\
\text { values }\end{array}$} & \multicolumn{2}{|c|}{ Confidence interval (95\%) } & \multirow[b]{2}{*}{ P-Values } \\
\hline & & & $\begin{array}{l}\text { Normal weight } \\
\qquad(n=13)\end{array}$ & Obese $(n=13)$ & \\
\hline Albumin & $\mathrm{mg} / \mathrm{dL}$ & $2.6-3.3$ & $2.9-3.3$ & $2.9-3.1$ & 0.587 \\
\hline ALT & $\mathrm{UI} / \mathrm{L}$ & $21-102$ & $24.9-55.5$ & $34.8-57.6$ & 0.559 \\
\hline HDL Cholesterol & $\mathrm{mg} / \mathrm{dL}$ & $33-120$ & $75.9-107.4$ & $104.1-144.3$ & $0.015^{*}$ \\
\hline Total Cholesterol & $\mathrm{mg} / \mathrm{dL}$ & $135-270$ & $130.6-161.1$ & $178-238.8$ & $0.0009 * *$ \\
\hline Creatinine & $\mathrm{mg} / \mathrm{dL}$ & $0.5-1.5$ & $0.7-1.0$ & $0.8-1.0$ & 0.673 \\
\hline ALP & UI/L & $20-156$ & $39.6-60.3$ & $40.0-100.5$ & 0.250 \\
\hline Globulin & $\mathrm{mg} / \mathrm{dL}$ & $2.7-4.4$ & $3.0-3.8$ & $3.6-4.6$ & $0.07^{\circ}$ \\
\hline Glucose & $\mathrm{mg} / \mathrm{dL}$ & $65-118$ & $64.3-70.8$ & $68.7-81.8$ & $0.04^{*}$ \\
\hline Total Protein & $\mathrm{mg} / \mathrm{dL}$ & $5,4-7,1$ & $6.2-6.8$ & $6.7-7.5$ & $0.06^{\circ}$ \\
\hline Triglycerides & $\mathrm{mg} / \mathrm{dL}$ & $20-112$ & $36.5-48.3$ & $39.9-163.6$ & $0.07^{\circ}$ \\
\hline Urea & $\mathrm{mg} / \mathrm{dL}$ & $21.4-59.92$ & $33.5-41.8$ & $30.2-38.8$ & 0.289 \\
\hline Insulin & $\mu \mathrm{U} / \mathrm{mL}$ & $5.0-20$ & $1.2-3.8$ & $1.4-4.4$ & 0.504 \\
\hline
\end{tabular}

ALT: alanine aminotransferase. ALP: alkaline phosphate. ${ }^{*} \mathrm{p} \leq 0.05 ;{ }^{*} \mathrm{p} \leq 0.01$ and ${ }^{\circ} \mathrm{p} \leq 0.1{ }^{{ }^{+}}$Reference values according to Kaneko (2008). 
concentrations (ABINAYA et al., 2018; PIANTEDOSI et al., 2016).

The enzymes ALP and ALT showed a tendency toward higher mean values in the obese group. PEÑA et al. (2008) found the same result, where the ALT and ALP values presented higher values when compared to the group with normal weight but without a significant difference. In another report, serum ALT was elevated in only 5 of 20 obese dogs studied (PIANTEDOSI et al., 2016). ALT was shown to have a strong correlation with directly measured liver fat content (Schindhelm et al., 2006) and metabolic syndrome (Tribuddharatana et al., 2011), which suggests that these results may be due to the reduced number of obese dogs with metabolic syndrome (2/13) found in this work.

Regarding the increase in HDL cholesterol in dogs, unlike humans, they mostly have HDL cholesterol lipoprotein in their circulation (SCHENCK, 2008), which represents $65 \%$ of total cholesterol in the majority of breeds (BAUER et al., 1996). In this study, it can be observed that obese dogs presented higher HDL cholesterol values, which may be related to the low incidence of atherosclerosis in dogs (BRUNETTO et al., 2011)

Concerning total cholesterol, only $15.38 \%$ of the animals were hypercholesterolemic. The occurrence of hyperlipidemia in dogs increases with age. This may explain the results of our study, which included predominantly young obese individuals with a mean age of four and a half years. This fact shows the importance of the study of the pathophysiology of obesity in dogs and the influence of the duration for which the animal is in the obese condition since it is known that hypercholesterolemia and hypertriglyceridemia are more significant in chronically obese dogs (KAWASUMI et al., 2014). Thus, factors such as age, duration of obesity, and type of diet may contribute to the increase in the concentration of total cholesterol and triglycerides (TVARIJONAVICIUTE et al., 2012).

Regarding metabolic syndrome, it is suggested that the affected dogs must present BCS $\geq 7$ / 9 and at least two of the following parameters: triglycerides $>200 \mathrm{mg} \cdot \mathrm{dL}^{-1}$, total cholesterol $>300 \mathrm{mg} \cdot \mathrm{dL}^{-1}$, glucose $>100 \mathrm{mg}^{\mathrm{dL}} \mathrm{dL}^{-1}$ and systemic arterial pressure $(\mathrm{SBP})>160 \mathrm{mmHg}$ (TVARIJONAVICIUTE et al., 2012). However, Shea et al. (2011) propose a new criterion to identify hyperlipidemia at an earlier stage, to prevent metabolic disorders. This new criterion suggests that the patient should present 2 of the following factors: triglycerides $\geq 165 \mathrm{mg}$. dL ${ }^{-1}$, total cholesterol $\geq 200 \mathrm{mg}$. dL 1 , and NEFA $\geq 15 \mathrm{mEq}$. $\mathrm{L}^{-1}$. In the present study, taking into account the other parameters, two patients $(2 / 13)$ had metabolic syndrome, and both presented BCS 8 .

The fat mass has no absolute correlation with metabolic syndrome, which means that obesity is not the only factor that triggers this dysfunction (TVARIJONAVICIUTE et al., 2012).

It is known that some obese humans are metabolically healthy, that is, they do not present hypercholesterolemia, hypertriglyceridemia, hyperglycemia, or insulin resistance (CHANG et al., 2016). In dogs, it is also not known that some dogs are "protected" from these metabolic changes (TVARIJONAVICIUTE et al., 2012).

In a report evaluating 62 dogs with metabolic syndrome, 39 animals $(62.9 \%)$ presented glucose $>100 \mathrm{mg} . \mathrm{dL}$ ${ }^{1}$, hypertriglyceridemia was observed in 57 dogs $(91.94 \%)$ and hypercholesterolemia was noted in 51 animals (82.26\%) (PIANTEDOSI et al., 2016). Another study evaluated 37 obese dogs and found that $31.43 \%$ had hyperglycemia, $8.57 \%$ had hypertriglyceridemia and $14.43 \%$ had hypercholesterolemia (TVARIJONAVICIUTE et al., 2012). This demonstrates the variability among individuals and that other factors beyond obesity should be associated; further studies are needed.

Regarding the evaluation of renal function, the results were within the normal range for creatinine and urea. However, in a study evaluating renal function in 37 obese dogs (KOVESDY et al., 2017), creatinine and urea values were observed within the reference values, but when testing new biomarkers such as cystatin $\mathrm{C}$, homocysteine, and clusterine, values indicative of possible subclinical renal dysfunction were found.

As for serum glucose, obese dogs presented a higher average glucose value when compared to dogs with normal weight. Dogs with experimentally induced obesity above $23 \%$ of their normal weight presented hyperglycemia from the 12 th week that persisted until the $32 \mathrm{nd}$ week, gaining 30\% more than the normal weight (ADOLPHE et al., 2014). Thus, it is suggested that the increase in glucose can be gradual and that this increase may be related to the degree of obesity about normal weight as well as the time that the animal has been in this condition, which makes more frequent veterinary check-ups necessary for obese dogs more frequently. These exams should be used to assess animal health so that the veterinarian can intervene early to prevent possible metabolic disorders.

Obese patients should receive check-ups more frequently, and these exams should be used to assess animal health so that the veterinarian can intervene early to prevent possible metabolic disorders

\section{CONCLUSION}

Biochemical alterations such as increased total cholesterol, HDL cholesterol, and glucose occur in obese dogs without clinical signs, in addition to a tendency toward higher values for total protein, globulins, and triglycerides. 


\section{REFERENCES}

ABINAYA, A. et al. Influence of age on blood biochemical profile of obese dogs. International Journal of Chemistry Study, v.6, n.3, p.991-993, 2018.

ADOLPHE, L.J. et al. Short-term obesity result in detrimental metabolic and cardiovascular changes that may not be reversed with weight loss in an obese dog model. British Journal of Nutrition, v.44, n. 11 , p. 647-656, 2014.

BAUER, J.E. Comparative lipid, and lipoprotein metabolism. Veterinary Clinical Pathology, v.2, p.49-56, 1996.

BURKHOLDER, W.J.; TOLL, P.W. Obesity. In: HAND, M.S. et al. Small Animal Clinical Nutrition. 4 ed. Topeka: Mark Morris Institute, p.401-425.

BBRUNETTO, M.A. et al. Correspondência entre obesidade e hiperlipidemia em cães. Ciência Rural, v.41, n.2, p.266-271, 2011.

CLARK, M.; HOENIG, M. Metabolic Effects of Obesity and Its Interaction with Endocrine Diseases. Veterinary Clinics of North American: Small Animal Practice, v.46, n.5, p.797-815, 2016.

CHANDLER, M. et al. Obesity and Associated Comorbidities in People and Companion Animals: A One Health Perspective. Journal Comparative Pathology, v.156, n.4, p.296-309, 2017.

CHANG, Y.et al. Metabolically Healthy Obesity and the Development of Nonalcoholic Fatty Liver Disease. American Journal of Gastroenterology, v.111, n.8, p.1133-1140, 2016.

DIEZ, M.; NGUYEN, P. Obesity: epidemiology, pathophysiology, and management of the obese dog. In: PIBOT, P. et al. Encyclopedia of canine clinical nutrition. Airmargues: Diffo Print, p.2-57, 2006.

ECKERSALL, P. D. Proteins, proteomics, and the dysproteinemias. In: KANEKO, et al. Clinical Biochemistry of Domestic Animals. 6 ed. San Diego, USA: Academic Press, p. 117-155, 2008.

GERMAN, A. J. Obesity in companion animals. In Practice, v.32, p.42-50, 2010.

KAWASUMI, K. et al. Age effects on plasma cholesterol and triglyceride profiles and metabolite concentrations in dogs. BMC Veterinary Research, v.10, n.57, p.1-5, 2014.
KEALY, R.D. et al. Effects of diet restriction on life span and agerelated changes in dogs. Journal of the American Veterinary Medicine Association, v.220, n.9, p.1315-1320, 2002.

KOVESDY, C.P.; FURTH, S.; ZOCCALI, C. Obesity, and kidney disease: Hidden consequences of the epidemic. Indian Journal of Nephrology, v.27, n.2, p.85-92, 2017.

LAFLAMME, D.P. Understanding and managing obesity in dogs and cats. Veterinary Clinics North American: Small Animal Practice, v.36, n.6, p.1283-1295, 2006.

MULLER, D.C.M.; SCHOSSLER J.E.; PINHEIRO M. Adaptação do índice de massa corporal humano para cães. Ciência Rural, v.38, n.4, p.1038-1043, 2008.

PEÑA, C. et al. Relationship between analytic values and canine obesity. Journal Animal Physiology Animal Nutrition, v.92, n.3, p.324-325, 2008.

PIANTEDOSI, D. et al. Serum biochemistry profile, inflammatory cytokines, adipokines, and cardiovascular findings in obese dogs. Veterinary Journal, v.216, p.72-78, 2016.

SHEA, J. L.; RANDELL, E. W.; SUN, G. The prevalence of metabolically healthy obese subjects defined by BMI and dual-energy X-ray absorptiometry. Obesity, v.19, n.3, p.624-630, 2011.

SCHENCK, P. Canine hyperlipidemia: causes and nutritional management. In: PIBOT, P. et al. Encyclopedia of canine clinical nutrition. Paris: Aniwa SAS, p.222-250, 2006.

TRIBUDDHARATANA, T. et al. Biochemical Alterations and Their Relationships with the Metabolic Syndrome Components in Canine Obesity. Kasetsart Journal-Natural Science. v.s/n, n.45, p.622-628, 2011.

TVARIJONAVICIUTE, A. et al. Obesity-related metabolic dysfunction in dogs: a comparison with human metabolic syndrome. BMC Veterinary Research. v.8, n.147, p.1-8, 2012.

TVARIJONAVICIUTE, A. et al. Evaluation of automated assays for immunoglobulin G, M, and A measurements in dog and cat serum. Veterinary Clinical Pathology, v.42, n.3, p.270280, 2013. 